\title{
Survey of neuroanesthesia fellowships in Canada
}

\author{
Darreul Sewell, MBChB, FRCA - Cynthia Henderson, MD, FRCPC • \\ Marie-Hélène Tremblay, MD, FRCPC • Hélène Pellerin, MD, FRCPC • \\ Alana M. Flexman, MD, FRCPC
}

Received: 5 September 2016/Revised: 24 September 2016/Accepted: 7 October 2016/Published online: 18 October 2016

(C) Canadian Anesthesiologists' Society 2016

\section{To the Editor,}

In the recent article by Kahn et al, we read with interest that $70 \%$ of Canadian anesthesia residents plan to pursue fellowship training. ${ }^{1}$ A recent survey of the membership of the Society of Neuroanesthesia and Critical Care (SNACC) demonstrated interest in pursuing accreditation, ${ }^{2}$ following which SNACC developed curriculum guidelines for neuroanesthesia fellowships. ${ }^{3}$ Although neuroanesthesia fellowships are offered in Canada, the prevalence and content are unknown. Given the lack of standardization of goals or objectives for neuroanesthesia fellowships in Canada, the content and structure may vary significantly. In addition, the support for accreditation in Canada is unclear. Our objectives were to determine the prevalence and characteristics of Canadian neuroanesthesia fellowships, identify barriers to the establishment of programs, and determine the level of support for standardization and accreditation of these fellowships.

Electronic supplementary material The online version of this article (doi:10.1007/s12630-016-0751-6) contains supplementary material, which is available to authorized users.

\section{Sewell, MBChB, FRCA}

Department of Neuroanaesthesia, National Hospital of

Neurology and Neurosurgery, University College London

Hospitals, Queens Square, London, UK

\section{Henderson, MD, FRCPC · A. M. Flexman, MD, FRCPC ( $\square)$} Department of Anesthesiology, Pharmacology, and Therapeutics Vancouver General Hospital, University of British Columbia, Vancouver, BC, Canada

e-mail: Alana.flexman@vch.ca

M.-H. Tremblay, MD, FRCPC - H. Pellerin, MD, FRCPC Department of Anesthesiology and Critical Care, Centre Hospitalier Universitaire de Québec, Hôpital Enfant-Jésus, Laval University, Québec, QC, Canada
Following approval from the University of British Columbia Behavioral Research Ethics Board (H1501640), we conducted a cross-sectional survey of all anesthesia departments with membership in the Association of Canadian University Departments of Anesthesia. We developed a web-based survey (http:// www.simplesurvey.com/) and e-mailed the survey link to the Neuroanesthesia Program Director identified on the respective university anesthesia department website between September 22, 2015 and November 2, 2015. If a Program Director was not identified, we instead contacted the Department Chair. We included questions about the presence and characteristics of a neuroanesthesia fellowship program, support for standardization of goals and objectives, and accreditation of neuroanesthesia fellowship programs in Canada (Appendix; available as Electronic Supplementary Material).

Of the 17 anesthesia departments contacted, ten (59\%) responded, including five of the eight (63\%) identified as having a neuroanesthesia fellowship on the Internet. Of note, $50 \%$ of the responding departments did not have a fellowship program. Among those with a fellowship, most had been active for more than ten years $(80 \%, n=4)$. All of the fellowships lasted one year and typically included a mix of clinical exposure to neuroanesthesia (two to three days/week) and research/academic activities (one day/ week), although the clinical exposure varied (Table 1). The programs were designed to accommodate one (60\%), two (20\%), or four (20\%) fellows per year. Program Directors thought that the number of applicants each year was either constant $(n=2)$ or increasing $(n=3)$. Barriers to program development were most frequently insufficient faculty (40\%), low departmental interest (30\%), low clinical volume (30\%), and remuneration (30\%). Although $80 \%$ $(n=4)$ of Fellowship Directors thought the development of 
Table 1 Content of neuroanesthesia programs in Canada

\begin{tabular}{|c|c|c|c|}
\hline Component & Frequently & Occasionally & Never \\
\hline Intracranial tumour surgery & $5(100 \%)$ & 0 & 0 \\
\hline Surgery for hydrocephalus & $5(100 \%)$ & 0 & 0 \\
\hline Complex spine surgery & $5(100 \%)$ & 0 & 0 \\
\hline Aneurysm/AVM surgery & $4(80 \%)$ & $1(20 \%)$ & 0 \\
\hline Functional neurosurgery & $4(80 \%)$ & $1(20 \%)$ & 0 \\
\hline Interventional neuroradiology & $4(80 \%)$ & $1(20 \%)$ & 0 \\
\hline Carotid endarterectomy & $4(80 \%)$ & $1(20 \%)$ & 0 \\
\hline Basic/clinical research & $4(80 \%)$ & $1(20 \%)$ & 0 \\
\hline Publication of article & $4(80 \%)$ & $1(20 \%)$ & 0 \\
\hline Presentation at conference & $4(80 \%)$ & $1(20 \%)$ & 0 \\
\hline Surgery for traumatic brain injury & $3(60 \%)$ & $1(20 \%)$ & $1(20 \%)$ \\
\hline Intraoperative neuromonitoring & $3(60 \%)$ & $1(20 \%)$ & $1(20 \%)$ \\
\hline Neurocritical care & $2(40 \%)$ & 0 & $3(60 \%)$ \\
\hline Epilepsy surgery & $1(20 \%)$ & $1(20 \%)$ & $3(60 \%$ \\
\hline $\begin{array}{l}\text { Transesophageal } \\
\text { echocardiography }\end{array}$ & 0 & $2(40 \%)$ & $3(60 \%)$ \\
\hline Pediatric neurosurgery & 0 & $1(20 \%)$ & $4(80 \%)$ \\
\hline
\end{tabular}

$\mathrm{AVM}=$ arteriovenous malformation.

national goals and objectives would be useful, only one supported formal accreditation.

The question of whether subspecialization in anesthesia changes outcomes remains uncertain, although a recent study suggested that appropriate subspecialty-trained clinicians improves patient outcomes. ${ }^{4}$ Recently, concern has been raised about the potential variability in the quality and experience of subspecialty training..$^{5}$ Standardization of fellowship content could be one solution. Interestingly, the majority of neuroanesthesia fellows in Canada appear to be international graduates, possibly reflecting the low level of interest in neuroanesthesia by Canadian residents reported by Kahn et al. ${ }^{1}$

Our survey suggests support for the development of a standardized curriculum, although our total number of respondents was low, and we did not capture all fellowship programs in our survey. Unlike the SNACC survey, wherein $64 \%$ of respondents supported some form of accreditation, $^{2}$ we found little support for accreditation in Canada. Although accreditation could potentially facilitate consistency of high-quality training, disadvantages might include longer training duration and additional expense with no guarantee of improved patient outcomes. ${ }^{2,6}$

In summary, the structure of neuroanesthesia fellowships in Canada appears to be consistent, although the content varies from one institution to another. The majority of fellows are international graduates, likely reflecting low interest among Canadian anesthesia residents. Whereas we identified interest in developing national goals and objectives, there was little interest in accreditation.
Competing interests and source of funding The authors have no competing interests to disclose. Dr. Alana Flexman is supported by a Vancouver Acute Department of Anesthesiology Research Merit Award.

Reprints Reprints will not be available from the corresponding author.

Editorial responsibility This submission is handled by Dr. Hilary P. Grocott, Editor-in-Chief, Canadian Journal of Anesthesia.

\section{References}

1. Khan J, Gilbert J, Sharma A, LeManach Y, Yee D. Perspectives of anesthesia residents training in Canada on fellowship training, research, and future practice location. Can J Anesth 2015; 62: 95663.

2. Mashour GA, Lauer K, Greenfield ML, et al. Accreditation and standardization of neuroanesthesia fellowship programs: results of a specialty-wide survey. J Neurosurg Anesthesiol 2010; 22: 252-5.

3. Mashour GA, Avitsian R, Lauer KK, et al. Neuroanesthesiology fellowship training: curricular guidelines from the Society for Neuroscience in Anesthesiology and Critical Care. J Neurosurg Anesthesiol 2013; 25: 1-7.

4. Varelas PN, Eastwood D, Yun HJ, et al. Impact of a neurointensivist on outcomes in patients with head trauma treated in a neurosciences intensive care unit. J Neurosurg 2006; 104: 713-9.

5. Mutter TC. Fellowships and subspecialization in anesthesia: Are they good, bad, or both? Can J Anesth 2016; 63: 887-8.

6. Bashore TM, Wang A. Recent accreditation council for graduate medical education initiatives have not been shown to improve the education of cardiology fellows. Circulation 2008; 118: 532-7 discussion 537. 